\title{
Diagnostic role of interleukin -33 in the differentiation of pleural effusions especially tuberculous and malignant effusions
}

\author{
Abdel-sadek Hamed Al-aarag ${ }^{1}$, Mohammad Hussein Kamel', Eman Ramadan Abdelgawad', \\ Shaimaa Magdy Abo-Youssef ${ }^{1}$, Hany Hussein Moussa ${ }^{2^{*}}$ (D), Marwa Elsayed Elnaggar ${ }^{1}$, \\ Rasha Mohammad Hendy ${ }^{1}$ and Koot Ahmad Diab ${ }^{1}$
}

\begin{abstract}
Background: Tuberculous pleurisy and malignancy are two of the most common causes of pleural effusion. IL-33 is expressed in the epithelial lining and endothelial cells and is released after cell damage; it is proposed to have an essential role in sensing damage in various infectious and inflammatory diseases. This work aimed to determine the diagnostic role of IL-33 in pleural effusions.

Methods: One hundred seventeen patients with pleural effusions of different etiologies had a quantitative measurement of IL-33 in their pleural effusion and serum samples by ELISA technique.

Results: The concentrations of IL-33 (mean \pm SD) in tuberculous pleural effusion (TPE) group $(22.5 \pm 0.90 \mathrm{ng} / \mathrm{l})$ were significantly higher than that of malignant pleural effusion (MPE) group $(14.6 \pm 2.35 \mathrm{ng} /$; $P<0.001)$. There is no significant difference between the serum levels of IL-33 in (TPE) group and (MPE) group ( $P>0.05)$. The concentrations of IL-33 in the pleural effusions were significantly correlated to that of the serum concentrations in each group (TPE: $r=0.848, P=<0.001$; MPE: $r=0.881,<0.001$ ) and pleural ADA in patients with tuberculous pleural effusions, $(r=0.38, P<0.001)$. The cut-off value of pleural IL33 for (TPE) was $19.16 \mathrm{ng} / \mathrm{l}$, with a sensitivity of $91.7 \%$, a specificity of $96.4 \%$. The cutoff point of a pleural/ serum IL-33 ratio for the diagnosis of TPE was $>1.4$ with a sensitivity of $91.7 \%$ and specificity of $100 \%$ while for the determination of (MPE) was $<0.9$ with a sensitivity of $83.3 \%$ and specificity of $96.4 \%$.
\end{abstract}

Conclusion: IL-33 level may serve as a novel biomarker to differentiate pleural effusions, especially tuberculous from malignant effusions.

Keywords: Pleural effusion, Tuberculosis pleurisy, Malignant pleural effusion

\section{Summary at a glance}

One hundred seventeen patients with pleural effusions of different etiologies had a quantitative measurement of IL-33 by ELISA technique in pleural effusion and serum samples of the patients. Pleural IL-33 is a novel biomarker for diagnosis and differentiation of different

\footnotetext{
* Correspondence: hany81eg@yahoo.com

${ }^{2}$ Faculty of medicine, Kafrelsheikh University, fifth foutoh salam street, Banha city, Qalubia Province 13518, Egypt

Full list of author information is available at the end of the article
}

forms of pleural effusion especially tuberculous from malignant effusions.

\section{Background}

Differentiating pleural effusions especially tuberculous pleural effusion from malignant pleural effusion is still a clinical challenge since they have similar clinical or laboratory manifestations and sometimes lack of pathological or etiological evidence [1]. Given the difficulties in ascertaining the etiology of pleural effusions from the simple fluid analysis, the need to new biomarkers 
emerges [2]. Cytokines as Interferon (IFN)- $\gamma$ and interleukin (IL)-1, - 6, - 16 and - 17 released from lymphocyte activation have proven to have differential and prognostic significance in tuberculous and malignant pleural effusions [3]. Interleukin 33 (IL-33) is a cytokine of the IL-1 superfamily; it previously named as the nuclear factor of high endothelial venules. It acts intracellularly as a nuclear factor and extracellularly as a cytokine. It induces helper $\mathrm{T}$ cells, mast cells, eosinophils, and basophils to produce type 2 (Th2) helper cell cytokines $[4,5]$. However, IL-33 is also capable of modulating type 1 helper (Th1) cell cytokine responses through inducing potent $\mathrm{CD} 8$ positive $\mathrm{T}$ cell responses in response to replicating, prototypic RNA and DNA viruses in mice [6] Some investigations showed that IL-33 expression increased in the pleural space of patients with tuberculous pleural effusion which induced by IFN- $\gamma$ and tumor necrosis factor (TNF) [7]. Tumor development results in down-regulation of IL-33 in epithelial cells but up-regulation of IL-33 in the tumor stroma and serum. IL-33 expression in tumor cells increases immunogenicity and promotes type 1 antitumor immune responses [8].

\section{Patients and methods}

A prospective study carried on 117 patients with pleural effusions of different etiologies; 72 (61.5\%) male and 45 females (38.5\%) and their ages ranged from 19 to 79 years (mean; $51.9 \pm 14.6$ ), admitted at Chest Department, Benha University Hospital during the period from September 2016 till August 2017. Ethical research approval from the institutional ethical committee and informed written consent from patients obtained. Patients classified according to their final diagnosis into four groups:

$$
\begin{aligned}
& \text { Group I: Included } 36 \text { cases (30.8\%), (18 males \& } 18 \\
& \text { females) of tuberculous pleural effusion; their } \\
& \text { ages ranged from } 30 \text { years to } 65 \text { years with a } \\
& \text { mean age of } 44.3 \pm 9.81 \text { years. } \\
& \text { Group II: Included } 33 \text { cases ( } 28.2 \%),(18 \text { males \& } 15 \\
& \text { females) of malignant pleural effusion } \\
& \text { secondary to mesothelioma (18 cases), } \\
& \text { metastatic adenocarcinoma (15 cases); their } \\
& \text { age ranged from } 19 \text { years to } 70 \text { years (mean } \\
& 54.9 \pm 14.6 \text { years). }
\end{aligned}
$$

Group III: Included 24 cases (20.5\%), (15 males \& 9 females) of parapneumonic pleural effusion; their age ranged from 26 years to 75 years with a mean age of $48.8 \pm 17.13$ years.

Group IV: Included 24 cases (20.5\%), (21 males \& 3 females) of transudative pleural effusion secondary to heart failure ( 3 cases), renal failure (3 cases) and liver cell failure (10 cases); their age ranged from 45 years 79 years with a mean age of $61.7 \pm 13.61$ years.

\section{Inclusion criteria}

Exudative pleural effusion was diagnosed first by using modified Light's criteria suggesting that pleural effusion is an exudate if effusion protein/serum protein ratio greater than 0.5 and or effusion lactate dehydrogenase (LDH)/serum LDH ratio greater than 0.6 [9], Table 1.

\section{Group I (tuberculous pleural effusions): (I \&ll Plus any of IV or V)}

I. Exudative pleural effusion identified.

II. The pleural effusion had an adenosine deaminase (ADA) concentration $>40 \mathrm{U} / 1$ [10]

III. Positive tuberculin skin test [11].

IV. Identification of acid-fast bacilli in the pleural effusion examination

V. Thoracoscopic or Abram's needle pleural biopsy revealed caseating granuloma [12].

\section{Group II (malignant pleural effusion)}

Symptomatic and rapidly accumulating pleural fluid (moderate to massive effusions occupying more than half of a hemithorax), and it had a chemical analysis proved to be exudative. Cytological examination revealed

\begin{tabular}{|c|c|c|c|c|c|c|c|c|c|}
\hline \multirow[t]{2}{*}{ GROUP } & \multirow[t]{2}{*}{ Age (years) } & \multicolumn{2}{|l|}{ Sex } & \multirow[t]{2}{*}{$\mathrm{PH}$} & \multirow{2}{*}{$\begin{array}{l}\text { Protein } \\
\text { gm/dl }\end{array}$} & \multirow{2}{*}{$\begin{array}{l}\mathrm{P} / \mathrm{S}^{*} \text { protein } \\
\text { ratio }\end{array}$} & \multirow[t]{2}{*}{$\mathrm{LDH}$} & \multirow{2}{*}{$\begin{array}{l}\mathrm{P} / \mathrm{S}^{*} \mathrm{LDH} \\
\text { ratio }\end{array}$} & \multirow[t]{2}{*}{$\operatorname{ADA}^{*}(U / L)$} \\
\hline & & Male & female & & & & & & \\
\hline $\mathrm{TB} \mathrm{No}=36$ & $44.3 \pm 9.81$ & 18 & 18 & $7.32 \pm 0.08$ & $4.4 \pm 0.8$ & $>0.5$ & $680(330-2322)$ & $>0.6$ & $81.6 \pm 29.4$ \\
\hline Malignancy No = 33 & $54.9 \pm 14.6$ & 18 & 15 & $7.33 \pm 0.06$ & $4.1 \pm 1.2$ & $>0.5$ & $560(151-2218)$ & $>0.6$ & - \\
\hline Para-pneumonic No $=24$ & $48.8 \pm 17.13$ & 15 & 9 & $7.30 \pm 0.09$ & $4.0 \pm 1.3$ & $>0.5$ & $502(133-8238$ & $>0.6$ & - \\
\hline Transudative $\mathrm{No}=24$ & $61.7 \pm 13.61$ & 21 & 3 & $7.40 \pm 0.05$ & $2+0.8$ & $<0.5$ & 142 (100-199) & $<0.6$ & - \\
\hline
\end{tabular}
exfoliative malignant cells or confirmed by immunohistochemistry or histopathological examination of the biopsies obtained by different methods of biopsy [13].

\section{Group III (parapneumonic effusion)}

Parapneumonic effusion is any pleural effusion secondary to pneumonia or lung abscess. The diagnosis considered when there was a clinical manifestation of pneumonia, radiological evidence of consolidation

Table 1 demographic data and routine biochemical analysis of pleural effusions

${ }^{*} \mathrm{P} / \mathrm{S}$ pleural / serum ratio, ${ }^{*} A D A$ Adenosine Deaminase 
associated with effusion and analysis of this fluid. Uncomplicated parapneumonic effusion is not purulent, and yields negative results on Gram stain and culture, it has $\mathrm{pH}$ higher than 7.2, glucose more significant than $40 \mathrm{mg} / \mathrm{dl}$ and lactate dehydrogenase (LDH) lower than $1000 \mathrm{IU} / \mathrm{l}$. While complicated parapneumonic effusion is purulent, and yields positive on either Gram stain or culture, with $\mathrm{pH}$ lower than 7.0, glucose lower than $40 \mathrm{mg} /$ $\mathrm{dl}$ and LDH greater than $1000 \mathrm{IU} / \mathrm{l}$ [14].

\section{Group IV (transudative pleural effusion)}

A- Patients with congestive heart failure (3 cases) diagnosed by the presence of the following evidence [15].

i. Chemical examination of the pleural fluid aspirate revealed transudative nature.

ii. Clinical symptoms and signs of heart failure; exertional dyspnea, orthopnea, paroxysmal nocturnal dyspnea, lower limb edema together with tachycardia or ventricular gallop and bilateral basal inspiratory crepitations.

iii. Cardiomegaly proved clinically, radiologically, or by echocardiography.

iv. Echocardiographical evidence of cardiac dysfunction (low left ventricular ejection fraction percentage)

B- Patients with liver cirrhosis and liver cell failure: (10 cases) were diagnosed according to the following criteria [16]:

i. Chemical examination of the pleural fluid aspirate revealed transudative nature.

ii. Clinical and laboratory evidence of hepatic injury, hypoalbuminemia,

iii. Portal hypertension guided by ultrasonographic examination.

C- Patients with renal failure (3 cases) diagnosed according to the following criteria [16].

i. Chemical examination of the pleural fluid aspirate revealed transudative nature.

ii. Clinical and laboratory evidence of renal impairment.

iii. Ultrasonographic evidence of renal affection.

Exclusion criteria: [17].

Patients with any of the following criteria excluded from the present study:

i. Treatment with antituberculous therapy or anticancer therapy

ii. The use of glucocorticoid and other antiinflammatory medication.
All patients subjected to the following:

i. Thorough medical history and physical examination,

ii. Routine laboratory investigations: CBC, ESR, coagulation profile, fasting, and two hours postprandial blood glucose. Liver and kidney functions tests. Serum total proteins \& LDH.

iii. Radiological examination: Plain chest X-ray (PA and lateral views), CT scans of the chest, abdominal $\mathrm{U} / \mathrm{S}$, and echocardiography whenever needed.

iv. Tuberculin skin test in T.B suspected cases: Using the Mantoux method.

v. Sputum examination for acid-fast alcohol fast bacilli (AFB) by ziehl -neelsen stain in T.B suspected cases.

vi. Diagnostic thoracocentesis with pleural sample centrifugation at $5000 \mathrm{rpm}$ for $10 \mathrm{~min}$ and stored at $\left(-80^{\circ} \mathrm{C}\right)$ until used for the assay.

vii. Collection and processing of the pleural fluid samples; Physical, chemical, bacteriological, cytological examination, and quantitative measurement of pleural fluid IL-33 using ELISA technique.

viii. Pleural biopsies: were taken for patients in groups (I and II) by either Abram's needle (3 cases, 2.5\%) or thoracoscope (63 cases, 54\%)

ix. Venous blood samples: For quantitative estimation of serum IL-33 by ELISA technique.

$\mathrm{x}$. Collection and processing of the blood samples: Blood samples $(3 \mathrm{cc})$ taken from the patients. Allowed to clot for $30 \mathrm{~min}$ and centrifugation separated the sera at about $5000 \mathrm{rpm}$ for $10 \mathrm{~min}$, sera were collected in pyrogen-free tubes and stored at $\left(-80^{\circ} \mathrm{C}\right)$ until used for the assay.

xi. IL-33 assay: Quantikine Human IL-33 Immunoassay is a 4.5-h solid phase ELISA (Quantikine ELISA, R\&D Systems China Co., Ltd) used to assay IL-33 in pleural and serum samples of our patients. It uses microplate pre-coated with a polyclonal antibody specific for human IL-33. Standards and patient samples were pipetted into the wells, so if any IL-33 present in the samples would be bounded to the particular polyclonal antibodies. The wells were washed to remove away any unbound substances. A substrate solution was then added to the wells to check color development in proportion to the amount of bounded IL-33, and then the intensity of the color is measured.

\section{Statistical analysis}

SPSS version 16 software (Spss Inc., Chicago, ILL Company) used to analyze the collected data, where the unequivocal data were given as number and percentages while quantitative data expressed as mean \pm standard 
Table 2 Comparison between pleural and serum IL-33 levels in all studied groups, tuberculous, malignant, parapneumonic and transudative groups

\begin{tabular}{|c|c|c|c|c|c|}
\hline \multicolumn{2}{|l|}{ Types of pleural effusion } & Range & Mean (ng/l) & Paired "t." & $P$ \\
\hline \multicolumn{2}{|c|}{ Pleural IL-33 of all studied group } & $6.44-23.95$ & $14.14 \pm 6.491$ & 2.7 & $0.01(S)^{*}$ \\
\hline \multicolumn{2}{|c|}{ Serum IL-33 of all studied group } & $5.23-20.32$ & $12.06 \pm 5.290$ & & \\
\hline \multirow[t]{2}{*}{ Tuberculous $N=36$} & Pleural IL-33 & $21.00-23.95$ & $22.5 \pm 0.90$ & 22.3 & $<0.001(\mathrm{HS})^{* *}$ \\
\hline & Serum IL-33 & $12.46-15.11$ & $13.9 \pm 0.85$ & & \\
\hline \multirow[t]{2}{*}{ Malignant $N=33$} & Serum IL-33 & $15.21-20.32$ & $13.5 \pm 1.98$ & 10.5 & $<0.01(\mathrm{~S})^{*}$ \\
\hline & Pleural IL-33 & $10.32-17.32$ & $11.9 \pm 2.35$ & & \\
\hline \multirow[t]{2}{*}{ Parapneumonic $N=24$} & Pleural IL-33 & $6.44-8.43$ & $7.33 \pm 0.72$ & 15.5 & $<0.001(\mathrm{HS})^{* *}$ \\
\hline & Serum IL-33 & $5.23-7.21$ & $6.22 \pm 0.76$ & & \\
\hline \multirow[t]{2}{*}{ Transudative $N=24$} & Pleural IL-33 & $7.12-8.21$ & $7.53 \pm 0.38$ & 10.5 & $<0.001(\mathrm{HS})^{* *}$ \\
\hline & Serum IL-33 & $5.38-6.78$ & $6.10 \pm 0.42$ & & \\
\hline
\end{tabular}

TST Tuberculin Skin Test ${ }^{*} S$ significant, ${ }^{* *} \mathrm{HS}$ highly significant

Shows that the pleural IL-33 level is significantly higher than the serum IL-33 level in all studied groups. Pleural IL-33 is significantly higher than the serum level in tuberculous, parapneumonic, and transudative groups; while serum IL-33 is significantly higher than the pleural level in the malignant group

deviation, and range, using Shapiro-Wilks test for normality, assuming normality at $P>0.05$, also paired " $\mathrm{t}$ " test, ANOVA and Person's correlation ( $r$ ) as proved to be normally distributed. ROC curve was used to detect cut off values of IL-33 in the prediction of tuberculous pleural effusion. The level of significance in this work started below $0.05(P<0.05$ was considered significant) [18].

\section{Results}

The pleural fluid IL-33 in all the studied groups level $(14.14 \pm 6.491 \mathrm{ng} / \mathrm{l})$ was significantly higher of that of the corresponding serum IL-33 levels $(12.6 \pm 5.29 \mathrm{ng} / \mathrm{l}$; $P<0.01)$. The mean pleural IL-33 levels of tuberculous group (22.5 \pm 0.9$)$, parapneumonic group $(7.33 \pm 0.72 \mathrm{ng} / \mathrm{l})$ and transudate group $(7.53 \pm 0.38 \mathrm{ng} / \mathrm{l})$ were significantly higher than the corresponding serum levels $(13.9 \pm 0.85$ $\mathrm{ng} / \mathrm{l} ; P<0.001),(6.22 \pm .76 \mathrm{ng} / \mathrm{l} ; P<0.001)$ and $(6.10 \pm .42$ ng/l; $P<0.001)$, respectively. However, serum IL-33 levels in the malignant group $(13.5 \pm 1.98 \mathrm{ng} / \mathrm{l})$ were higher than the corresponding pleural level (11.9 \pm $2.35 \mathrm{ng} / \mathrm{l} ; P<0.01$ ), Table 2 .

The concentrations of IL-33 in the pleural effusion positively correlated with that of the corresponding serum samples in all patients of the study groups $(r=$ $0.677, P<0.001)$. The concentrations of pleural IL33 in tuberculous, malignant and parapneumonic pleural effusion groups were also positively correlated with their corresponding serum IL33 level $(r=0.848, P<0.001 ; r=$ $0.881, P<0.001$; and $r=0.965, P<0.001)$ respectively. Also, Pleural IL-33 positively correlates with pleural ADA in patients with tuberculous pleural effusions, $(r=$ $0.38, P<0.001$ ), Table 3 .

The concentrations of IL-33 in the pleural effusion of the tuberculous group $(22.5 \pm 0.90 \mathrm{ng} / \mathrm{l})$ were considerably more than that of the malignant group $(14.6 \pm 2.35$ $\mathrm{ng} / \mathrm{l} ; \mathrm{P}<0.001)$ or that of parapneumonic group $(7.33 \pm$ $0.32 \mathrm{ng} / \mathrm{l} ; \mathrm{P}<0.001)$ and transudative group $(7.53 \pm 0.38$ ng/l; $\mathrm{P}<0.001)$, Table 4.

The serum IL-33 level was statistically significantly higher in the tuberculous group $(13.90 \pm 0.85 \mathrm{ng} / \mathrm{L})$ than that of parapneumonic $(6.22 \pm 0.72 \mathrm{ng} / \mathrm{l} ; P<0.001)$ group and transudative group $(6.10 \pm 0.42 \mathrm{ng} / \mathrm{l} ; \quad P<0.001)$. However, there was no significant difference between serum IL-33 in tuberculous $(13.90 \pm 0.85 \mathrm{ng} / \mathrm{L})$ and malignant $(13.5 \pm 1.98 \mathrm{ng} / \mathrm{L} ; P>0.05)$ groups, Table 5 .

A $19.16 \mathrm{ng} / \mathrm{l}$ was the cutoff point of pleural IL-33 level for the diagnosis of tuberculous pleural, with a sensitivity

Table 3 Correlation between serum and pleural IL-33 levels in different studied samples

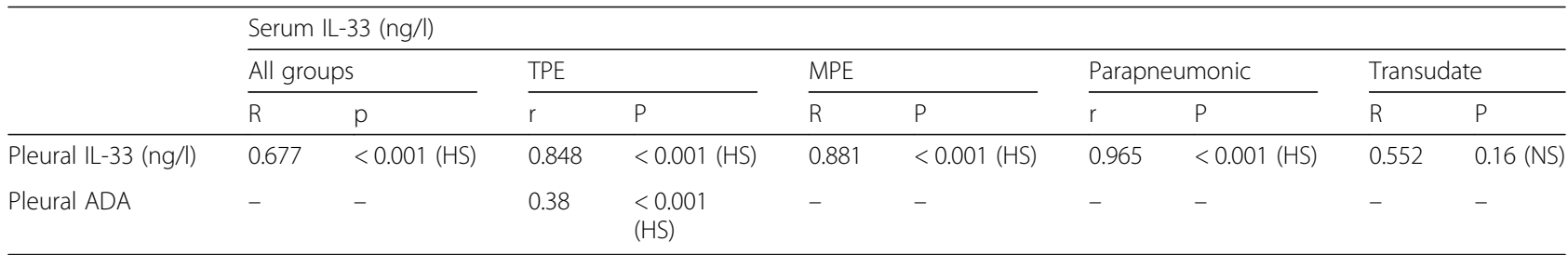

TPE Tuberculous pleural effusion, MPE pleural effusion

There is a significant positive correlation between serum and pleural IL-33 levels in all groups of the study and each group; tuberculous, malignant and parapneumonic pleural effusions but not in transudative pleural effusion. Pleural IL-33 positively correlates with pleural ADA in patients with tuberculous pleural effusions, $(r=0.38, P<0.001)$ 
Table 4 Comparison between pleural IL-33 levels in each studied groups

\begin{tabular}{|c|c|c|c|c|}
\hline Effusion & Range & Mean & Paired " $t$ " & $P$ \\
\hline Pleural IL-33 in TPE N=36 & $21.0-23.95$ & $22.5 \pm 0.90$ & 10.7 & $<0.001(\mathrm{HS})$ \\
\hline Pleural IL-33 in MPE N=33 & $10.32-17.32$ & $14.6 \pm 2.35$ & & \\
\hline Pleural IL-33 in Parapneumonic group $N=24$ & $6.44-8.43$ & $7.33 \pm 0.72$ & 39.7 & $<0.001(\mathrm{HS})$ \\
\hline Pleural IL-33 in transudative group $N=24$ & $7.12-8.21$ & $7.53 \pm 0.38$ & 34.9 & $<0.001(\mathrm{HS})$ \\
\hline Serum IL-33 in TPE N=36 & $12.46-15.11$ & $13.90 \pm 0.85$ & 6.73 & $>0.05$ (NS) \\
\hline Serum IL-33 in MPE $N=33$ & $15.21-20.32$ & $13.50 \pm 1.98$ & & \\
\hline
\end{tabular}

TPE Tuberculous pleural effusion, MPE malignant pleural effusion

This table shows that pleural IL-33 is significantly higher in tuberculous pleural effusion than in malignant, parapneumonic, and transudative pleural effusion groups

of $91.7 \%$ and specificity of $96.4 \%$. The serum IL-33 level of tuberculous pleural effusion group was between 9.83$15.16 \mathrm{ng} / \mathrm{l}$, with a sensitivity of $100 \%$ and specificity of 96.4\% Table 6, Fig. 1.

The cutoff point of the pleural/ serum IL-33 ratio for the diagnosis of tuberculous 'pleural effusion was $>1.4$; with a sensitivity of $91.7 \%$ and specificity of $100 \%$. The cutoff point of the pleural/serum IL-33 ratio for the diagnosis of malignant pleural effusion was $<0.9$, with a sensitivity of $83.3 \%$ and specificity of $96.4 \%$, Table 7 , Fig. 2.

\section{Discussion}

IL-33 has been suggested to have a role in the pathogenesis of pleural inflammation and effusion [19]. IL-33 may serve as a novel biomarker to differentiate pleural effusions, especially tuberculous from malignant effusions. The pleural fluid IL-33 levels were significantly higher of the corresponding serum IL-33 levels in all our studied groups moreover, it was considerably higher in each subgroup, however, serum IL-33 levels in the malignant group were significantly higher than the corresponding pleural level and might be used to differentiate it from other causes of pleural effusions Table 2. This significant serum-pleural IL-33 difference of the malignant group could be explained by that the tumor development results in down-regulation of IL-33 in epithelial cells but upregulation of IL-33 in the tumor stroma and serum [8].

In this study, the positive correlations of pleural effusions IL-33 concentrations with the corresponding serum samples of all patients of the study groups $(\mathrm{r}=$ $0.677, P<0.001)$; moreover, the positive correlation of subgroups; pleural IL33 in tuberculous, malignant and parapneumonic pleural effusion groups with their corresponding serum IL33 level $(r=0.848, P<0.001 ; r=0.881$, $P<0.001$; and $r=0.965, P<0.001)$ respectively was in agreement with Xuan et al., Lee et al. and Li et al., who in their studies found that; the concentrations of IL-33 in the pleural effusions of tuberculous, malignant and parapneumonic groups positively correlated with that of the corresponding serum samples [17, 20, 21]. ,Also, pleural IL-33 was positively correlated with pleural ADA in patients with tuberculous pleural effusions, $(r=0.38$, $P<0.001$ ), Table 3 , in accordance to koung et al. and Lee et al. who demonstrated statistically significant positive correlations between IL-33 levels and ADA [20]. This positive correlation makes the test more reliable in diagnosing tuberculous pleural effusion.

In this study, the significant higher pleural and serum IL-33 concentrations in tuberculous pleural effusion group more than other groups, Table 4, and the nonsignificant difference found between serum IL-33 in tuberculous and malignant $(P>0.05)$ groups, Table 5, strongly points to tuberculous etiology and could be used to differentiate it from malignant cause. Similarly, Xuan et al., Lee et al. and Li et al. demonstrated tuberculous pleural effusion IL-33 levels were significantly higher than malignant pleural effusion IL-33 levels $[17,20,21]$. Xuan et al. and Li et al. also found a nonsignificant difference between serum IL-33 in tuberculous and malignant groups [17, 21]. However, Lee et al., disagree these results and found that levels of serum IL-33 $(26 \mathrm{pg} / \mathrm{mL})$ significantly higher in patients with tuberculous

Table 5 Comparison between serum IL-33 levels in each studied groups

\begin{tabular}{lllll}
\hline Effusion & Range & Mean & Paired "t." & P \\
\hline Serum IL-33 in TPE $N=36$ & $12.46-15.11$ & $13.90 \pm 0.85$ & 6.73 & \\
Serum IL-33 in MPE $N=33$ & $15.21-20.32$ & $13.50 \pm 1.98$ & & \\
Serum IL-33 in Parapneumonic group N=24 & $5.23-7.21$ & $6.22 \pm 0.76$ & 20.5 & $<0.001(\mathrm{HS})$ \\
Serum IL-33 in transudative group $N=24$ & $5.38-6.67$ & $6.10 \pm 0.42$ & 23.9 & $<0.001(\mathrm{HS})$ \\
\hline
\end{tabular}

TPE Tuberculous pleural effusion, MPE malignant pleural effusion

This table shows that serum IL-33 is significantly higher in tuberculous pleural effusion than of parapneumonic and transudative pleural effusion groups. However, there was no significant difference between serum IL-33 in tuberculous and malignant groupse 
Table 6 Cutoff value, sensitivity, specificity, the positive predictive value of serum and pleural IL-33 level in the prediction of tuberculous pleural effusion

\begin{tabular}{llllllllll}
\hline Variable & Cutoff & Sens\% & Spec\% & PPV\% & NPV\% & Accuracy\% & AUC & $95 \% C l$ & P \\
\hline Serum IL-33 in TPE & $>9.83-15.16$ & $100 \%$ & $57.1 \%$ & $50 \%$ & $100 \%$ & $70 \%$ & 0.607 & $0.43-0.78$ & $0.29(\mathrm{NS})$ \\
Pleural IL-33 in TPE & $>19.16$ & $91.7 \%$ & $96.4 \%$ & $91.7 \%$ & $96.4 \%$ & $95 \%$ & 0.973 & $0.92-1.0$ & $<0.001(\mathrm{HS})$ \\
Combined & & $100 \%$ & $96.4 \%$ & $92.3 \%$ & $100 \%$ & $97.5 \%$ & 0.982 & $0.94-1$ & $<0.001(\mathrm{HS})$
\end{tabular}

TPE Tuberculous pleural effusion, MPE malignant pleural effusion

This table shows that the cutoff value of pleural IL-33 level for the diagnosis of tuberculous pleural effusion is $19.16 \mathrm{ng} / \mathrm{l}$. So IL-33 levels more than this threshold give a high probability of being tuberculous pleural effusion. The area under the corresponding ROC curve (AUC) was 0.973 . The $95 \%$ confidence interval is $0.92-1$, the corresponding sensitivity and specificity are 91.7 and $96.4 \%(P<0.01)$. Pleural and serum IL-33 level combination increase the sensitivity to $100 \%$ and specificity to $96.4 \%$

pleural effusion than that of malignant pleural effusion $(16$ $\mathrm{pg} / \mathrm{mL}, P=0.03)[20]$.

The cutoff point of the studied pleural IL-33 levels for the diagnosis of tuberculous pleural effusion was; 19.16 ng/l with $91.7 \%$ sensitivity and $96.4 \%$ specificity. The serum IL-33 level of the tuberculous group was between $9.83-15.16 \mathrm{ng} / \mathrm{l}$; therefore patients with serum and pleural level of IL-33 at these ranges had a high probability of being diagnosed with tuberculous pleural effusion with a sensitivity of $100 \%$ and specificity of $96.4 \%$, Table 6. While the cutoff point of the pleural/ serum IL-33 ratio for the diagnosis of tuberculous 'pleural effusion was $>1.4$; therefore patients with pleural/serum IL-33 ratio $>1.4$ had a high probability of being diagnosed with tuberculous pleural effusion with 91.7\% sensitivity and 100\% specificity. The cutoff point of the pleural/serum IL-33 ratio for the diagnosis of malignant pleural effusion was $<0.9$; therefore patients with pleural/serum IL-33 ratio $<0.9$ had a high probability of being diagnosed with malignant pleural effusion with $83.3 \%$ sensitivity and $96.4 \%$ specificity, Table 7 .

Xuan et al. found that the cut-off value of pleural IL33 for the diagnosis of tuberculous pleural effusion was; $19.86 \mathrm{ng} / \mathrm{l}$ with $86.96 \%$ sensitivity and $90.48 \%$ specificity [17]. $\mathrm{Li}$ et al. found that the area under curve (AUC) of IL-33 to differentiate tuberculous pleural effusion from all non- tuberculous pleural effusions 0.823 (95\% CI, $0.737-0.909$ ) with a cut-off value of $68.3 \mathrm{pg} / \mathrm{ml}$, the sensitivity and specificity were 83.9 and $70.9 \%$, respectively [21].

$\mathrm{Ni}$ Zeng and colleges carried out a systematic review over 38 studies to study the interleukins value for diagnosis of tuberculous pleural effusion, and found that the sensitivity, specificity for the selected ILs were: IL-2, 0.67and, 0.76; IL-6, 0.86 and, 0.84; IL-12, 0.78 and, 0.83;

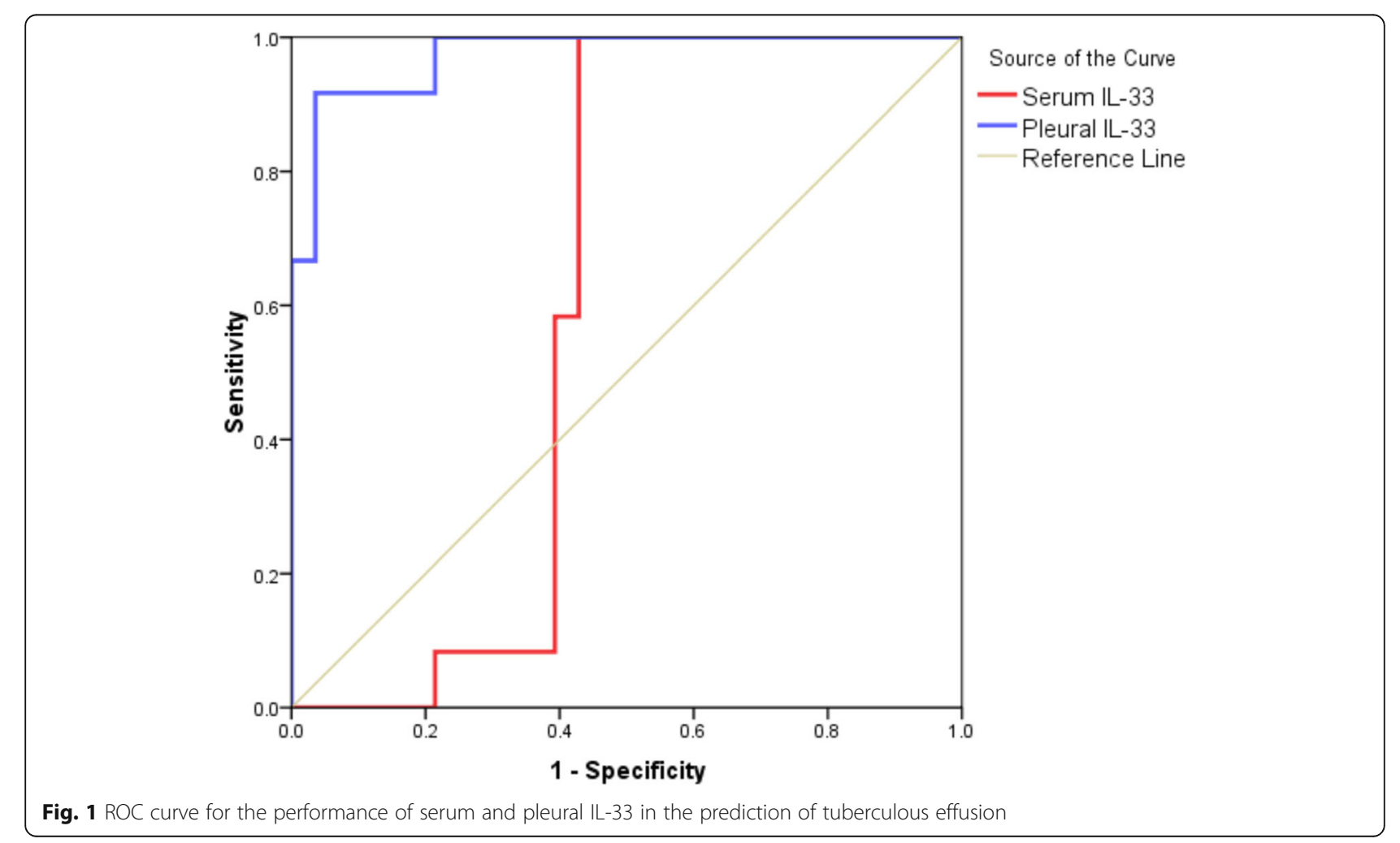


Table 7 Cutoff value, sensitivity, specificity, positive predictive value, and negative predictive value of pleural/serum IL-33 ratio in the prediction of tuberculous effusion

\begin{tabular}{llllllllll}
\hline Variable & Cutoff & Sens\% & Spec\% & PPV\% & NPV\% & Accuracy\% & AUC & $95 \% C l$ & P \\
\hline Pleural/serum ratio & $>1.4$ & $91.7 \%$ & $100 \%$ & $100 \%$ & $96.5 \%$ & $97.5 \%$ & 0.94 & $0.85-1.0$ & $<0.001(\mathrm{HS})$ \\
Pleural/serum ratio & $<0.9$ & $83.3 \%$ & $96.4 \%$ & $90.9 \%$ & $93.1 \%$ & $92.5 \%$ & 0.90 & $0.77-1.0$ & $<0.001(\mathrm{HS})$
\end{tabular}

The cutoff value of pleural/serum IL-33 ratio for the diagnosis of tuberculous pleural effusion was $>1.4$. Therefore patients with pleural/serum IL-33 ratio $>1.4$ had a high probability of having a tuberculous pleural effusion. The value for the area under the corresponding ROC curve (AUC) was 0.94 . The $95 \%$ confidence interval was $0.85-1.0$; the corresponding sensitivity and specificity were 91.7 and $100 \%(P<0.001)$. The cutoff value of pleural/serum IL-33 ratio for the diagnosis of malignant pleural effusion is $<0.9$, therefore patients with pleural/serum IL-33 ratio $<0.9$ has a high probability of having a malignant pleural effusion. The value for the area under the corresponding ROC curve (AUC) is 0.90 . The $95 \%$ confidence interval was $0.77-1.0$, the corresponding sensitivity and specificity were 83.3and $96.4 \%(P<0.001)$

IL-12p40, 0.82 and, 0.65; IL-18, 0.87 and, 0.92; IL-27, 0.93 and, 0.95 [22]. Wang and colleges had two prospective studies and one meta-analysis study to assess the diagnostic accuracy of IL-27 in tuberculous pleural effusion; in Beijing study, they reported $96.1 \%$ sensitivity and $99.0 \%$ specificity with an area under the curve of 0.983 when the cut-off value was $591.4 \mathrm{ng} / \mathrm{L}$. Also, the superior diagnostic accuracy of interleukin 27 reported by Wuhan cohort study and confirmed in their metaanalysis study [23]. These results were comparable to the pleural IL-33 level in the tuberculous pleural effusion of this study $(91.7 \%$ sensitivity and $96.4 \%$ specificity).

This study has some limitations as; a small number of patients used to confirm the diagnostic role of IL-33, so broader scale study on a large number of patients is needed to verify the diagnostic role of IL-33. This study was carried out in a high prevalence TB area (Egypt); other studies are required to assess low TB prevalence populations, and how would their results differ from high TB prevalence populations? IL-33, like many different biomarkers, cannot be relied on for definitive diagnosis and pleural intervention is still needed to confirm the diagnosis. However, IL-33 can be used as a diagnostic aid in cases of pleural effusions to guide further investigations as it is a stable and affordable biomarker that can be measured in serum and pleural effusion, our data supports its use as a novel biomarker in a high prevalence population, and further study in low prevalence populations is warranted.

\section{Conclusion}

the present study showed that the mean pleural IL-33 levels were significantly higher than that of serum in all

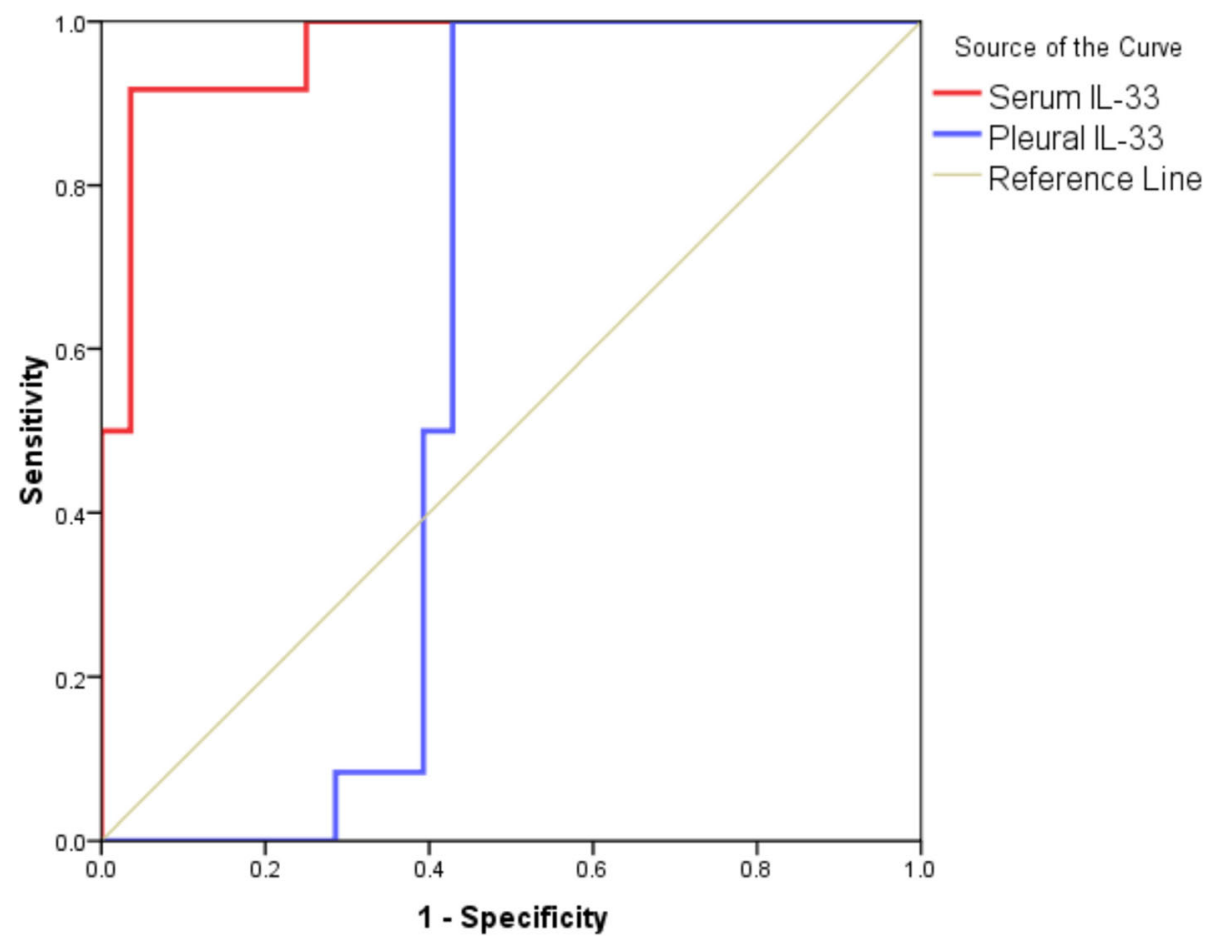

Fig. 2 ROC curve for the performance of serum and pleural IL-33 in the prediction of malignant effusion 
study groups except in the malignant group where serum levels were higher than pleural levels. The cutoff point of pleural IL-33 level for the diagnosis of tuberculous pleural effusion was $19.16 \mathrm{ng} / \mathrm{l}$ with sensitivity of $91.7 \%$, specificity of $96.4 \%$ and the cutoff point of pleural/ serum IL- 33 ratio for diagnosis of tuberculous pleural effusion was $>1.4$ with sensitivity of $91.7 \%$ and specificity of $100 \%$ and for the determination of malignant pleural effusion was $<0.9$ with sensitivity of $83.3 \%$ and specificity of $96.4 \%$. Pleural IL-33 is a novel, fast $(4.5 \mathrm{~h})$, reliable biomarker assay for the differentiation of pleural effusion especially tuberculosis from the malignant pleural effusion.

\section{Abbreviations}

ADA: Adenosine deaminase; AFB: Acid-fast bacilli; AUC: Area under the curve; CBC: Complete blood count; CT: Computed tomography; ESR: Erythrocyte sedimentation rate; IFN-ү: Interferon- Gamma; IL: Interleukin; LDH: Lactate dehydrogenase; MPE: Malignant pleural effusion; NF-kB: Nuclear factor Klight-chain-enhancer of activated B cells; ng/l: Nanogram/litre;

T.B: Tuberculosis; Th1: Type 1 helper cell; Th2: Type 2 helper cell; TNF: Tumor necrosis factor; TPE: Tuberculous pleural effusion

\section{Authors' contributions}

Dr. AHA and Dr. MHK make the study design and critical revision of the manuscript; Dr. ERA and KAD make the data acquisition and analysis; Dr. HHM; Dr. SMA; Dr. MEE and Dr. RMH make the manuscript drafting and critical revision of the manuscript and sharing in data analysis. However, all authors approved the final manuscript.

\section{Funding}

None.

\section{Availability of data and materials}

The datasets used and/or analysed during the current study are available from the corresponding author on reasonable request.

\section{Ethics approval and consent to participate}

Ethical research approval had been granted from Benha University hospital's ethical committee and informed written consent had been obtained from all participants.

\section{Consent for publication}

Not applicable.

\section{Competing interests}

The authors declare that they have no competing interests.

\section{Author details}

${ }^{1}$ Faculty of medicine, Benha University, Banha city, Qalubia Province 13518, Egypt. ${ }^{2}$ Faculty of medicine, Kafrelsheikh University, fifth foutoh salam street, Banha city, Qalubia Province 13518, Egypt.

Received: 2 June 2018 Accepted: 11 June 2019

Published online: 25 June 2019

\section{References}

1. Wu YB, Ye ZJ, Qin SM, Wu C, Chen YQ, Shi HZ. Combined detections of interleukin 27, interferon- $\gamma$, and adenosine deaminase in pleural effusion for diagnosis of tuberculous pleurisy. Chin Med J. 2013;126:3215-21.

2. Wong CF, Yew WW, Leung SK, Chan CY, Hui M, Au-Yeang C, et al. Assay of pleural fluid interleukin-6, tumor necrosis factor-alpha and interferongamma in the diagnosis and outcome correlation of tuberculous effusion. Respir Med. 2003;97:1289-95.

3. Qin XJ, Shi HZ, Huang ZX, Kang LF, Mo WN, Wu C. Interleukin-16 in tuberculous and malignant pleural effusions. EurRespir J. 2005;25:605-11.
4. Carriere V, Roussel L, Ortega N, Lacorre DA, Americh L, Aguilar L, Bouche G, et al. IL-33, the IL-1-like cytokine ligand for ST2 receptor, is a chromatinassociated nuclear factor in vivo. Proc Natl Acad Sci U S A. 2007;104:282-7.

5. Tjota MY, Williams JW, Lu T, Clay BS, Byrd T, Hrusch CL, et al. IL-33dependent induction of allergic lung inflammation by FcyRIII signaling. J Clin Invest. 2013;123:2287-97.

6. Bonilla W, Fröhlich A, Senn K, Kallert S, Fernandez M, Johnson S, et al. The alarmin interleukin-33 drives protective antiviral CD8+ T cell responses. Science. 2012;335:984-9.

7. Qama D, Choi WI, Kwon KY. Immune responses in the lungs of patients with tuberculous pleural effusion without pulmonary tuberculosis. B MC Immunol. 2012;13:45.

8. Lu B, Yang M, Wang Q. Interleukin-33 in tumorigenesis, tumor immune evasion, and cancer immunotherapy. J Mol Med (Berl). 2016;94(5):535-43.

9. Light RW, Erozan YS, Ball WC. Cells in pleural fluid, their value in the differential diagnosis. Arch Intern Med. 1973;132(6):854-60.

10. Burgess $L$, Maritz FJ, Le Roux I, Taljaard JJ. Use of adenosine deaminase as a diagnostic tool for tuberculous pleurisy. Thorax. 1995;50:672-4.

11. Valdés D, Álvarez E, San José P, Penela P, Valle JM, García-Pazos JM, et al. Tuberculous pleurisy. A study of 254 cases. Arch Intern Med. 1998;158:2017-21.

12. Diacon AH, Van de Wal BW, Wyser C, Smedema JP, Bezuidenhout J, Bolliger $C T$, et al. Diagnostic tools in tuberculous pleurisy: a direct comparative study. EurRespir J. 2003;22:589-91.

13. Beauchamp HD, Kundra NK, Aranson R, Chong F, MacDonnell KF. The role of closed pleural needle biopsy in the diagnosis of malignant mesothelioma of the pleura. Chest. 1992;102:1110-2.

14. Light RW. Parapneumonic effusions and empyema. In: Light RW, editor. Pleural diseases. 3a ed. Baltimore: Williams \& Wilkin; 1995. p. 129-53.

15. Porcel JM, Light RW. Diagnostic approach to pleural effusion in adults. AmFam Physician. 2006;73:1211-20.

16. Light RW. Pleural Diseases. 5th ed. Baltimore, MD: Lippincott, Williams and Wilkins; 2007.

17. W Zhang J, Zhou Q, Yang WB, Ma LJ. Role of interleukin -33 in the differentiation between tuberculous and malignant pleural effusion. Oncol Lett. 2014;8:449-53.

18. Kothari CR. Research methodology. New Delhi: new age international; 2004.

19. Xuan W-X, Zhang J-C, Zhou Q, Yang W-B, Ma L-J. IL-33 levels differentiate tuberculous pleurisy from malignant pleural effusions. Oncol Lett. 2014;8(1): 449-53.

20. Lee K-S, Kim H-R, Kwak S, Choi KH, Cho JH, Lee YJ, et al. Association between elevated pleural Interleukin-33 levels and tuberculous pleurisy. Ann Lab Med. 2013;33(1):45-51. https://doi.org/10.3343/alm.33.1.45.

21. Li D, Shen Y, Fu X, Li M, Wang T, Wen F. Combined detections of interleukin-33 and adenosine deaminase for diagnosis of tuberculous pleural effusion. Int J Clin Exp Pathol. 2015;8(1):888-93.

22. Zeng N, Wan C, Qin J, Wu Y, Yang T, Shen Y, Wen F, Chen L. Diagnostic value of interleukins for tuberculous pleural effusion: a systematic review and meta-analysis. BMC Pulm Med. 2017;17:180.

23. Wang W, Zhou Q, Zhai K, Wang Y, Liu JY, Wang XJ, Wang Z, Zhang JC, Tong $Z \mathrm{ZH}$, Shi HZ. Diagnostic accuracy of interleukin 27 for tuberculous pleural effusion: two prospective studies and one meta-analysis. Thorax. 2018;73(3):240-7.

\section{Publisher's Note}

Springer Nature remains neutral with regard to jurisdictional claims in published maps and institutional affiliations.
Ready to submit your research? Choose BMC and benefit from:
- fast, convenient online submission
- thorough peer review by experienced researchers in your field
- rapid publication on acceptance
- support for research data, including large and complex data types
- gold Open Access which fosters wider collaboration and increased citations
- maximum visibility for your research: over $100 \mathrm{M}$ website views per year
At $\mathrm{BMC}$, research is always in progress.
Learn more biomedcentral.com/submissions 